\title{
Peran Direct Fed Microbials (DFM) Saccharomyces cerevisiae dan Aspergillus oryzae terhadap Produktivitas Ternak Ruminansia : Review
}

\author{
The Role of Direct Fed Microbials (DFM) Saccharomyces cerevisiae and \\ Aspergillus oryzae on Ruminant Productivity : A Review \\ H. Suryani, M. Zain, N. Jamarun, dan R.W.S. Ningrat \\ Jurusan Nutrisi dan Makanan Ternak, Fakultas Peternakan, Universitas Andalas \\ Kampus Limau Manis, Padang - 25163, Indonesia \\ e-mail : henysuryani92@yahoo.com \\ (Diterima: 14 November 2014; Disetujui: 17 Januari 2015)
}

\begin{abstract}
ABSTRAK
Mikroorganisme yang biasa digunakan dalam pakan ternak ruminansia biasanya berupa probiotik. Probiotik memiliki makna yang bersepadanan dengan Direct Fed Microbials (DFM). Penambahan DFM jenis Saccharomyces cerevisiae dan Aspergillus oryzae pada pakan ternak ruminansia mampu memanipulasi rumen dengan meningkatkan populasi bakteri pemecah serat sehingga dapat meningkatkan kecernaan dan meningkatkan bobot badan. Mekanisme kerja $S$. cerevisiae dan $A$. oryzae yang masuk kedalam tubuh ternak dan mempengaruhi pencernaan atau penyerapan, ada yang sudah diketahui secara jelas tetapi ada juga yang masih berupa hipotesa. Pemanfaatan DFM jenis $S$. cerevisiae dan A. oryzae secara tunggal maupun kombinasi sebagian telah diamati dan memberikan respon positif.

Kata kunci : direct fed microbials, Saccharomyces cerevisiae, Aspergillus oryzae, produktivitas, ruminansia.

ABSTRACT

Microorganisms used in ruminant feed is usually in the form of probiotics. Probiotics have a corresponding meaning with Direct Fed microbials (DFM). The addition of DFM, such as Saccharomyces cerevisiae and Aspergillus oryzae in ruminants feed increased the population of rumen fiber degragader bacterials. This effort aimed at improving the digestibility and in turn enhancing ruminant body weight. While the working mechanism of S. cerevisiae and A. oryzae entering into the animal's body and affect digestion or absorption have been already known, still some hypothesa should be tested. In fact, DFM utilization of S. cerevisiae and A. oryzae either by indvidual or a combination had been observed and give a positive response.
\end{abstract}

Keywords : direct fed microbials, Saccharomyces cerevisiae, Aspergillus oryzae, productivity, ruminant.

\section{PENDAHULUAN}

Pemanfaatan limbah perkebunan sebagai pakan ternak dapat dijadikan sebagai alternatif untuk mengatasi masalah ketersediaan pakan ternak ruminansia khususnya sapi potong. Limbah hasil perkebunan seperti pelepah sawit umumnya berkualitas rendah karena tingginya kandungan selulosa dan hemiselulosa yang berikatan dengan lignin, sehingga nilai nutrisi maupun kecernaannya rendah. Pakan berserat tinggi dapat menurunkan efisiensi fermentasi pakan di dalam rumen. Oleh sebab itu pemanfaatan limbah hasil perkebunan sebagai pakan ternak sapi potong perlu diselaraskan dengan usaha untuk meningkatkan efisiensi fermentasi pakan. Upaya-upaya untuk meningkatkan 
kegunaan pakan berserat tinggi telah banyak dilakukan melalui pengolahan bahan pakan baik secara fisik, kimiawi, atau biologis (Preston dan Leng, 1987). Namun pengolahan saja belum memberikan hasil yang optimal pada ternak (Zain et al., 2002 ).

Pada ternak ruminansia proses pencernaan dalam rumen sangat bergantung pada populasi dan jenis mikroba rumen. Pada dasarnya proses perombakan pakan adalah aktivitas enzim yang dihasilkan oleh mikroba rumen. Oleh karena itu, usaha memanfaatkan pakan serat disamping melalui pengolahan juga diikuti usaha untuk mengoptimalkan pertumbuhan mikroba rumen dengan pemberian suplemen tambahan. Salah satu pendekatan yang dapat digunakan adalah dengan penambahan suplemen probiotik atau mikroba hidup (Mustangwa et al., 1992). Fuller (1989) mendefenisikan DFM sebagai pakan tambahan berupa mikroorganisme hidup yang diberikan langsung pada ternak yang dapat mempengaruhi dan menguntungkan ternak inang dengan meningkatkan keseimbangan ekosistem rumen. Proses pencernaan rumen dapat dimanipulasi dengan penambahan DFM untuk meningkatkan pencernaan, meningkatkan performans ternak, dan meningkatkan kesehatan ternak (Desnoyers et al., 2009). Saccharomyces cerivisiae merupakan DFM yang kaya akan enzim, vitamin, dan kofaktor penting lainnya (Dawson, 1993), sedangkan Aspergillus oryzae mengandung enzim selulase yang merangsang pertumbuhan mikroorganisme selulolitik (Offer, 1990). Kedua DFM ini dapat memberikan respon yang sama terhadap populasi selulolitik (Yoon dan Stern, 1996). Peningkatan populasi ini disebabkan DFM tersebut dapat memanfaatkan oksigen dalam rumen sehingga keadaaan menjadi lebih anaerob dan mengakibatkan meningkatnya jumlah mikroba yang hidup. Penambahan DFM diharapkan dapat meningkatkan jumlah populasi mikroba rumen dan meningkatkan efisiensi fermentasi rumen.

Tulisan ini akan mereview peran DFM dalam mencerna serat, proses dan hasilnya pada ternak ruminansia, yang dibatasi pada
DFM species khamir/yeast (S. cerevisiae) dan species jamur (A. oryzae).

\section{Direct Fed Microbials (DFM)}

Penggunaan mikroba sebagai suplemen ternak ruminansia bukanlah suatu hal yang baru, DFM memiliki arti kata yang bersepadanan dengan probiotik. Cara kerja probiotik adalah dengan membantu menurunkan derajat keasaman dan menghambat pertumbuhan organisme penganggu dalam sistem pencernaan. Fuller (1992) dan Roberfoid (2000) menyatakan bahwa DFM merupakan imbuhan pakan berupa mikroorganisme hidup yang menguntungkan dan mempengaruhi induk semang melalui perbaikan keseimbangan mikroorganisme dalam saluran pencernaan. Fuller (2002) menyatakan bahwa keseimbangan mikroba tercapai apabila mikroorganisme yang menguntungkan dapat menekan mikroorganisme yang merugikan. DFM juga dapat menghasikan produk akhir antimikroba berupa asam yang dapat menghambat pertumbuhan bakteri patogen (Denev, 2006), selanjutnya dinyatakan bahwa prinsip kerja DFM meliputi kompetisi untuk mendapatkan zat makanan, tempat adhesi pada dinding usus, dan penghambatan secara langsung terhadap kehidupan mikroba yang dikalahkan. Konsep utama dari pemanfaatan DFM pada ternak ruminansia adalah kemampuan DFM memodifikasi ekosistem rumen (Seo et al., 2010). DFM di bidang peternakan bermanfaat bagi kesehatan, efisiensi fermentasi rumen, produksi dan pencegahan penyakit ternak. Menurut Suharsono (1994) mikroba yang termasuk dalam kelompok DFM mempunyai ciri sebagai berikut yaitu: 1) dapat diproduksi dalam skala industri; 2) jika disimpan di lapangan akan stabil dalam jangka waktu yang lama; 3) mikroorganisme harus dapat hidup kembali dalam saluran pencernaan; dan 4) memberikan manfaat pada induk semang.

Suplementasi DFM merupakan salah satu pilihan pakan tambahan pada ternak yang sehat dan aman bagi lingkungan (Cole, 1991). Pada umumnya, probiotik diberikan pada ternak yang mengkonsumsi serat tinggi dan hanya satu laporan yang memberikan Starbio pada ternak yang konsumsi konsentratnya 
tinggi (Ngadiyono dan Baliarti, 2001). Hal ini menunjukkan bahwa penambahan probiotik untuk ternak ruminansia lebih ditujukan agar rumen dapat mencerna lebih baik pakan yang berserat tinggi.

\section{Jenis - Jenis DFM}

Mikroorganisme yang bisa digunakan dalam DFM untuk ternak ruminansia meliputi spesies Lactobacillus, Bifidobacterium, Enterococcus, Streptococcus, Bacillus, Saccharomyces, Aspergillus dan Propionibacterium. Jenis kamir yang umum digunakan untuk DFM pada ternak ruminansia adalah S. cerevisiae (Shin et al., 1989). Jamur yang sering digunakan adalah Aspergillus niger dan Aspergillus oryzae (Chen et al., 2004). Penggunaan mikroba tersebut memberikan keuntungan pada peningkatan efisiensi fermentasi dalam rumen, peningkatan kecernaan hijauan dan peningkatan laju aliran protein mikroba dari rumen (Wallace dan Newbold, 1992).

\section{Peran DFM dalam Mencerna Serat Kasar pada Ternak Ruminansia}

Dalam usaha meningkatkan efisiensi pemanfaatan pakan untuk menghasilkan produk ternak secara optimal, mikroba rumen berperan dalam membantu pemecahan zat gizi dalam pakan dan mengubahnya menjadi senyawa yang dapat dimanfaatkan oleh ternak. Pakan yang berserat merupakan pakan yang biasa untuk ternak ruminansia, namun pemecahan komponen serat (selulosa, hemiselulosa dan lignin) sangat tergantung pada aktivitas enzimatis mikroba rumen serta sifat degradabilitas komponen serat tersebut. Beberapa penelitian telah menunjukkan bahwa aktivitas enzimatis mikroba rumen dapat dirangsang melalui induksi sintesis enzim maupun peningkatan populasi mikroba tertentu (Hobson dan Jouany, 1988).

\section{Mekanisme kerja DFM S. cerevisiae pada Ternak Ruminansia}

Mekanisme kerja DFM $S$. cerevisiae pada prinsipnya seperti probiotik lainnya yakni secara fermentatif dengan mula mula mensekresikan enzim $\alpha$-galaktosidase dan $\beta$-glukosidase menyerang ikatan senyawa sakarida untuk menguraikan senyawa oligosakarida (vebraskosa, sciosa dan rafinosa) menjadi gula-gula sederhana (di dan mono sakarida) dan kemungkinan melepaskan zatzat nutrisi yang terikat oleh senyawa sakarida sehingga terbuka bagi enzim pencernaan ( $\mathrm{Li}$ et al., 2004).

DFM S. cerevisiae merupakan faktor pertumbuhan bagi bakteri selulotik karena dapat menyediakan nutrien yaitu vitamin, mineral dan asam amino untuk pertumbuhan bakeri tersebut (Wina, 2000). Meningkatnya jumlah populasi bakteri selulolitik akan meningkatkan aktifitas selulolitik untuk mencerna serat. Aktifitas pernafasan yeast culture dapat menurunkan potensi redoks (Dawson et al. 1990).

Yeast culture menggunakan oksigen untuk metabolisme partikel pakan menjadi gula dan oligosakarida dalam menghasilkan peptida dan asam amino sebagai produk akhir yang digunakan oleh bakteri. Sebagian besar mikroorganisme rumen bersifat anaerob, maka pemanfaatan oksigen oleh yeast culture akan meningkatkan kondisi optimum di dalam rumen. Kondisi tersebut, akan melindungi bakteri rumen anaerob dari kerusakan oleh $\mathrm{O}_{2}$. Menciptakan kondisi yang lebih baik untuk pertumbuhan bakteri selulolitik, sehingga jumlah bakteri selulolitik meningkat dan meningkatkan pencernaan dalam rumen (Jouany, 2001). S. cerevisiae juga mampu memproduksi asam glutamat sehingga dapat meningkatkkan palatabilitas pada pakan ternak, sehingga meningkatkan konsumsi pakan dan pada akhirnya dapat meningkatkan produktivitas ternak. Suplementasi yeast juga mampu meransang acetogens untuk bersaing memanfaatkan hidrogen dengan methanogen, sehingga dapat mengurangi emisi metan (Mwenya et al., 2004). Dengan berkurangnya produksi metan dalam rumen, maka dapat meningkatkan energi pakan yang pada akhirnya memberikan efek positif terhadap produktivitas ternak.

Mekanisme kerja DFM Aspergillus oryzae pada Ternak Ruminansia

Kapang Aspergillus oryzae dikenal
sebagai kapang yang banyak meng-


Tabel 1. Ringkasan model kerja DFM untuk ruminansia dari referensi hasil penelitian sejak 1991

\begin{tabular}{|c|c|c|c|}
\hline Bacteria & Aplikasi & Reference & Mode of action \\
\hline 1 & 2 & 3 & 4 \\
\hline \multicolumn{4}{|l|}{ Lactic acid producers } \\
\hline \multirow[t]{3}{*}{ Enterococcus faecium } & $\mathrm{C}$ & Nocek et al. (2003) & Stimulasi pemanfaatan asam laktat \\
\hline & $\mathrm{F}$ & Emmanuel et al (2007) & Sebagai antibakteri \\
\hline & $\mathrm{L}$ & Abas et al (2007) & Meningkatkan respon imune \\
\hline \multirow[t]{2}{*}{ Lactobacillus case } & $\mathrm{D}$ & Yasuda et al. (2007) & \\
\hline & $\mathrm{L}$ & Lema et al. (2001) & \\
\hline $\begin{array}{l}\text { Lactobacillus acidophilus } \\
\text { Rumen bacteria }\end{array}$ & $\mathrm{C}$ & Al- Saiady (2010) & \\
\hline \multirow[t]{2}{*}{ Megaspharea elsdenii } & $\mathrm{D}$ & Henning et al. (2010) & Meningkatkan propionat \\
\hline & $\mathrm{F}$ & Leeuw et al. (2009) & Modulator $\mathrm{pH}$ \\
\hline $\begin{array}{l}\text { Prevotella bryantii } \\
\text { Other }\end{array}$ & $\mathrm{D}$ & Chiqueete et al. (2008) & \\
\hline $\begin{array}{l}\text { Propianibacterium } \\
\text { freudenreichii }\end{array}$ & $\mathrm{F}$ & Vasconcelos et al. (2008) & Menigkatkan propionat \\
\hline $\begin{array}{l}\text { Propianicbacterium } \\
\text { jensenii }\end{array}$ & $\mathrm{C}$ & Adam et al (2008) & Modulator $\mathrm{pH}$ \\
\hline Bifidobacterium spp. & $\mathrm{C}$ & Krehbiel et al. (2003) & Menurunkan fungssi saluran cerna \\
\hline \multirow[t]{2}{*}{ Bacillus spp. } & $\mathrm{C}$ & Aydin et al. (2009) & Penyerapan substrat \\
\hline & $\mathrm{F}$ & Arthur et al. (2010) & \\
\hline \multicolumn{4}{|l|}{ Yeast and Fungi } \\
\hline \multirow[t]{5}{*}{ Saccharomyces cerevisiae } & $\mathrm{C}$ & Kalmus et al. (2009) & $\begin{array}{l}\text { Mempercepat pembentukan } \\
\text { mikroba pada ternak yang baru lahir }\end{array}$ \\
\hline & $\mathrm{D}$ & Liou et al. (2009) & Meningatkan keernaan serat \\
\hline & $\mathrm{F}$ & Thrune et al. (2009) & $\begin{array}{l}\text { Meningkatkan pemanfaatan asam } \\
\text { laktat }\end{array}$ \\
\hline & $\mathrm{L}$ & $\begin{array}{l}\text { Chaucheryas-Durand et al. } \\
\text { (2010) }\end{array}$ & Mampu menghilangkan oksigen \\
\hline & & & $\begin{array}{l}\text { Stimulasi growth factor/nutrient } \\
\text { Sumber dari enzim hidrolisis }\end{array}$ \\
\hline Aspergillus oryzae & $\mathrm{F}$ & Miranda et al. (1996) & \\
\hline
\end{tabular}

Ket : C, Calves; D, Dairy cattle; F, Feedlot cattle; L, Lamb

Sumber : McAllister et al. (2011)

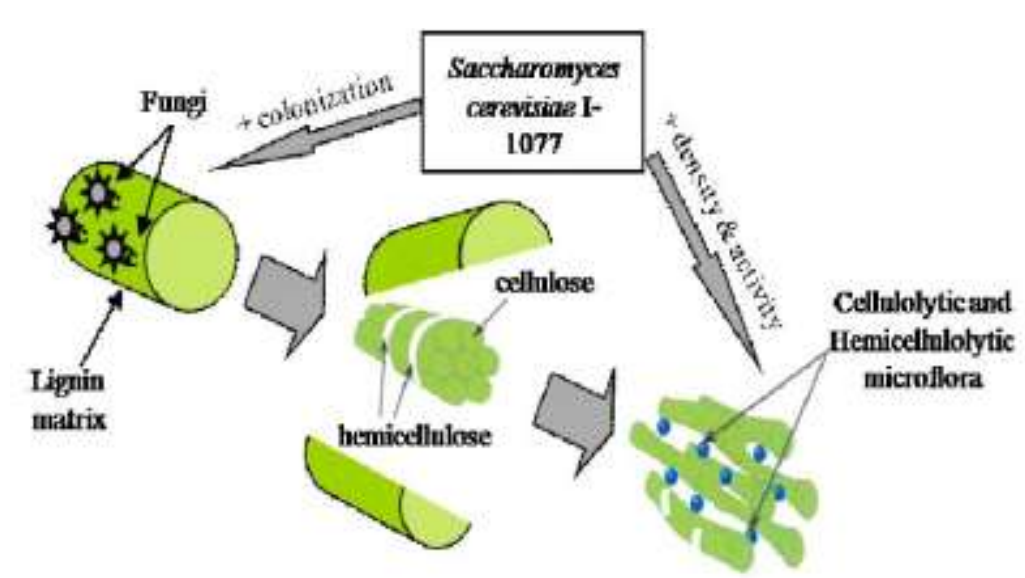

Gambar 1. Proses S. cerevisiae memecah serat 
Tabel 2. Perkembangan penelitian suplementasi DFM S. cerevisiae pada ternak ruminansia

\begin{tabular}{|c|c|c|c|c|}
\hline Peneliti & Strain & Dosis & Ternak & Effect \\
\hline 1 & 2 & 3 & 4 & 5 \\
\hline $\begin{array}{l}\text { Arambel and Kent } \\
\text { (1990) }\end{array}$ & S. cerevisiae & $90 \mathrm{~g} / \mathrm{d}$ & $\begin{array}{l}\text { Sapi } \\
\text { perah }\end{array}$ & $\begin{array}{l}\text { Suplementasi SC tidak memberikan } \\
\text { efek yang signifikan terhadap } \\
\text { kecernaan protein, ADF dan NDF } \\
\text { antar perlakuan }\end{array}$ \\
\hline William et al. (1991) & $\begin{array}{l}\text { S. cerevisiae plus } \\
\text { growth medium } \\
(\mathrm{YC})\end{array}$ & $10 \mathrm{~g} \mathrm{YC} / \mathrm{d}$ & $\begin{array}{l}\text { Sapi } \\
\text { perah }\end{array}$ & $\begin{array}{lrr}\text { Suplementation } & \text { yeast } & \text { culture } \\
\text { meningkatkan kecernaan } & \text { bahan } \\
\text { kering dan produksi susu. } & \end{array}$ \\
\hline $\begin{array}{l}\text { Yoon and Stern } \\
\text { (1995) }\end{array}$ & $\begin{array}{l}\text { S. cerevisiae } \\
\text { A. oryzae }\end{array}$ & $57 \mathrm{~g} / \mathrm{d}$ & $\begin{array}{l}\text { Sapi } \\
\text { perah }\end{array}$ & 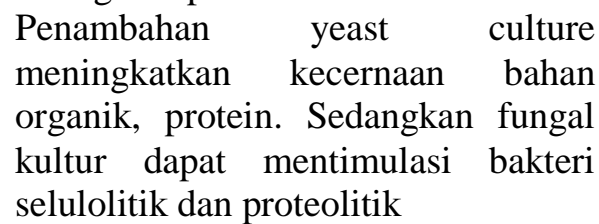 \\
\hline Oetzel et al. (2007) & S. cerevisiae & $\begin{array}{l}5 \times 10^{9} \\
\mathrm{cfu} / \mathrm{cow} / \mathrm{d}\end{array}$ & $\begin{array}{l}\text { Sapi } \\
\text { perah }\end{array}$ & $\begin{array}{l}\text { Meningkatkan persentase lemak susu, } \\
\text { dan protein susu. }\end{array}$ \\
\hline Mikulec et al. (2010) & S. cerevisiae & $\begin{array}{l}0,5 \mathrm{~g} / \mathrm{d} \text { dan } \\
1 \mathrm{~g} / \mathrm{d}\end{array}$ & Domba & $\begin{array}{l}\text { Suplementasi } 0,5 \mathrm{~g} / \mathrm{d} \text { dan } 1 \mathrm{~g} / \mathrm{d} \mathrm{YC} \\
\text { belum meningkatkan perfomance } \\
\text { ternak domba. }\end{array}$ \\
\hline Inal et al. (2010) & S. cereviae & $4 \mathrm{~g} / \mathrm{d}$ & Domba & $\begin{array}{l}\text { Menurunkan kosentrasi asetat dan } \\
\text { meningkatkan propionat }\end{array}$ \\
\hline Zain et al. (2011) & S. cerevisiae & $\begin{array}{l}0,0,25 \% \\
0,50 \% \text { dan } \\
0,75 \%\end{array}$ & In vitro & $\begin{array}{l}\text { Suplementasi } S . \text { cerevisiae dapat } \\
\text { meningkatkan populasi bakteri } \\
\text { dibanding kontrol namun tidak } \\
\text { berbeda nyata antar perlakuan. } 0,29 \\
\text { vs } 4,99,5,12 \text {, dan } 6,01 .\end{array}$ \\
\hline $\begin{array}{l}\text { Grochowska } \\
\text { et al. }(2012)\end{array}$ & S. cerevisiae & $15 \mathrm{~g} / \mathrm{d}$ & Domba & $\begin{array}{l}\text { Penambahan H-NDF dan L-NDF } \\
\text { tidak dapat merubah pH, ammonia, } \\
\text { kosentrasi VFA dan persentase molar } \\
\text { asetat, proponat dan butirat. Namun } \\
\text { jika dibandingkan dengan kontrol L } \\
\text { DF dapat meningkatkan propionat. }\end{array}$ \\
\hline
\end{tabular}

hasilkan bermacam jenis enzim, diantaranya $\alpha$-amilase, $\alpha$-glaktosidase, glutaminase, proteinase, dan $\beta$-glukosidase (Yano, 1988). Berdasarkan hasil penelitian yang telah ada Offer (1990) dan Newblod (1990) mencoba membuat suatu diagram alur (tahap 1 - 3) tentang pendugaan model cara kerja probiotik jamur pada ternak ruminansia (Gambar 2). Peningkatan produktivitas pada ternak dipengaruhi oleh peningkatan konsumsi pakan (tahap 1). Peningkatan konsumsi ini terjadi akibat meningkatnya laju cerna serat (tahap 2a) dan meningkatnya laju alir protein mikroba (tahap 2b). Peningkatan laju pencernaan serat akan menyebabkan perbaikan pertumbuhan mikroorganisme, karena terpenuhinya kebutuhan hidup minimal bagi perkembangbiakan mikroorganisme (Hobson dan Wallace, 1982). Penggunaan probiotik jamur menyebabkan peningkatan populasi mikroorganisme dalam rumen, sebagai akibat terjadinya perbaikan daya hidup mikroorganisme (tahap 3a dan tahap 3b). Tahap $4-6$ merupakan penggambaran dari hasil penelitian William (1989) dan William et al. (1991). Perbaikan daya hidup mikroorganisme ini terjadi karena stabilnya $\mathrm{pH}$ rumen yang merupakan pengaruh sekunder (tahap 4). Kestabilan $\mathrm{pH}$ rumen diduga disebabkan oleh penurunan asam laktat dalam rumen (tahap 5). Sebagian besar strain khamir tidak membentuk asam laktat kecuali S. cerevisiae. 


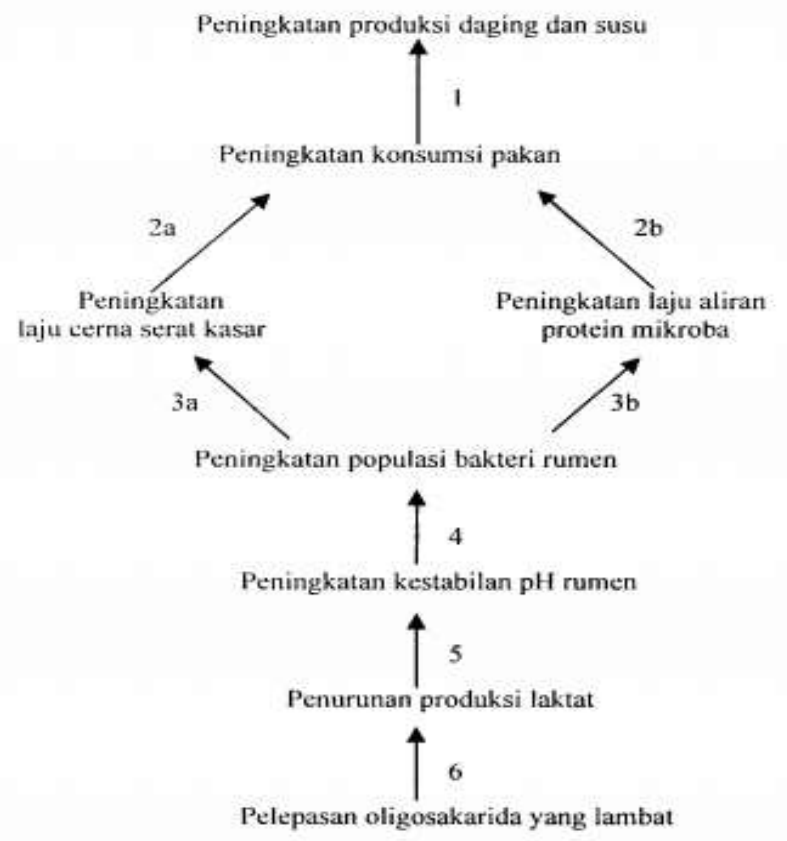

Gambar 2. Pendugaan model cara kerja probiotik jamur. Sumber : Newbold (1990)

Tabel 3. Perkembangan penelitian suplementasi DFM A. oryzae pada ternak ruminansia

\begin{tabular}{|c|c|c|c|c|}
\hline Peneliti & Strain & Dosis & Animal & Efek \\
\hline 1 & 2 & 3 & 4 & 5 \\
\hline $\begin{array}{l}\text { Gomez-Alarcon } \\
\text { et al. (1989) }\end{array}$ & A. oryzae & $3 \mathrm{~g} / \mathrm{d}$ & Sapi perah & $\begin{array}{l}\text { Meningkatkan kecernaan fraksi } \\
\text { serat dalam rumen }\end{array}$ \\
\hline $\begin{array}{l}\text { Beharka et al. } \\
\text { (1991) }\end{array}$ & A. oryzae & $5 \times 10 \mathrm{cfu} / \mathrm{ml}$ & In vitro & $\begin{array}{l}\text { Mengingkatkan kosentrasi total } \\
\text { VFA, propionat, asetat dalam } \\
\text { rumen }\end{array}$ \\
\hline $\begin{array}{l}\text { Beharka and } \\
\text { Nagaraja (1993) }\end{array}$ & $\begin{array}{l}\text { A. oryzae fermentation } \\
\text { extract }\left(\text { Amaferm }^{\circledR}\right)\end{array}$ & $1,2 \mathrm{~g} / \mathrm{L}$ & In vitro & $\begin{array}{l}\text { Suplementasi Amaferm }{ }^{\circledR} \text { dapat } \\
\text { meningkatkan kecernan serat } \\
\text { dengan menstimulasi pertumbu- } \\
\text { han bakteri rumen namun tidak } \\
\text { terhadap fungal dan aktifitas } \\
\text { protozoa }\end{array}$ \\
\hline $\begin{array}{l}\text { Lubis et al. } \\
(2002)\end{array}$ & $\begin{array}{l}\text { A. oryzae } \\
\text { Fermentation Culture } \\
\text { (AOFC) }\end{array}$ & $\begin{array}{l}0 \%, 5 \% \\
\text { dan } 10 \%\end{array}$ & Domba & $\begin{array}{l}\text { Pemberian AOFC } 10 \% \text { dapat } \\
\text { meningkatkan populasi bakteri } \\
\text { selulolitik, karakteristik cairan } \\
\text { rumen, kecernaan serat dan } \\
\text { kecernaan protein dari } 59,6 \% \\
\text { pada domba kontrol menjadi } \\
65,5 \% \text { dengan suplementasi } \\
10 \% \text { AOFC. }\end{array}$ \\
\hline $\begin{array}{l}\text { Sosa et al. } \\
\text { (2011) }\end{array}$ & $\begin{array}{l}\text { A. oryzae pada } \\
\text { substrat } \text { Penisettum } \\
\text { purpureum vs Cuba } \\
\text { CT- } 169 \text {. }\end{array}$ & $\begin{array}{l}\text { Dosis pertama } 0, \\
50,100 \text { dan } 200 \\
\mathrm{ml} \text {. Dosis kedua } 0, \\
0,5,5,25 \text { dan } 50 \\
\mathrm{ml} / 50 \mathrm{ml}\end{array}$ & In vitro & $\begin{array}{l}\text { Percobaan } 100 \mathrm{ml} \text { menurunkan } \\
\text { produksi asam asetat, butirat } \\
\text { dan meningkatkan propionat, } \\
\text { meningkatkan KCBK dan VFA }\end{array}$ \\
\hline
\end{tabular}


Tabel 4. Perkembangan penelitian suplementasi beberapa jenis DFM pada ternak ruminansia

\begin{tabular}{|c|c|c|c|c|}
\hline Peneliti & Strain & Dosis & Ternak & Efek \\
\hline 1 & 2 & 3 & 4 & 5 \\
\hline $\begin{array}{l}\text { Wiedmeier et al. } \\
\text { (1987) }\end{array}$ & $\begin{array}{l}\text { yeast culture, ekstrak } \\
\text { fermentasi } A \text {. oryzae dan } \\
\text { kombinasi keduanya }\end{array}$ & $\begin{array}{c}90 \mathrm{~g} / \mathrm{d} \text { dan } \\
2,63 \mathrm{~g} / \mathrm{d}\end{array}$ & Sapi perah & $\begin{array}{l}\text { KCBK meningkat dengan penamba- } \\
\text { han } A \text {. oryzae dan kombinasi } A \text {. } \\
\text { oryzae dan yeast culture. KCP } \\
\text { meningkat dengan penambahan yeast } \\
\text { culture. Kecernaan hemiselulosa, } \\
\text { total bakteri selulolitik, ratio asetat } \\
\text { dan propionat meningkat dengan } \\
\text { kombinasi keduanya. }\end{array}$ \\
\hline Chiquette (1995) & $\begin{array}{l}\text { S. cerevisiae dan } \\
\text { A. oryzae }\end{array}$ & $\underset{1}{10 \mathrm{~g} \mathrm{head}^{-1} \mathrm{~d}^{-}}$ & Sapi perah & $\begin{array}{l}\text { Suplementasi AO individu atau } \\
\text { kombinasi dengan SC dapat mensti- } \\
\text { mulasi kosentrasi asetat, propionat } \\
\text { dan total VFA. Meningkatkan rasio } \\
\text { produksi susu. }\end{array}$ \\
\hline $\begin{array}{l}\text { Yoon and } \\
\text { Stern (1995) }\end{array}$ & $\begin{array}{l}\text { S. cerevisiae } \\
\text { dan fungal culture } \\
\text { A. oryzae }\end{array}$ & $\begin{array}{c}57 \mathrm{~g} / \mathrm{d} \text { dan } 3 \\
\mathrm{~g} / \mathrm{d}\end{array}$ & $\begin{array}{l}\text { Sapi perah } \\
\text { Laktasi }\end{array}$ & $\begin{array}{l}\text { Penambahan yeast culture mening- } \\
\text { katkan kecernaan bahan organik, } \\
\text { protein. Sedangkan fungal kultur } \\
\text { dapat menstimulasi bakteri selulolitik } \\
\text { dan proteolitik. }\end{array}$ \\
\hline $\begin{array}{l}\text { Latif et al. } \\
(2014)\end{array}$ & $\begin{array}{l}\text { S. cerevisiae, A. oryzae } \\
\text { dan kombinasi keduanya }\end{array}$ & $\begin{array}{c}0.5 \mathrm{~g} / \mathrm{d} \\
0.5 \mathrm{~g} / \mathrm{d} \\
0.5 \text { and } 0.5 \\
\text { g/d }\end{array}$ & Domba & $\begin{array}{l}\text { Suplementasi AO dan SC+AO me- } \\
\text { ningkatkan konsumsi bahan kering } \\
5 \% \text { dan } 9 \% \text {. Suplementasi SC, AO } \\
\text { dan SC+AO tidak berpengaruh } \\
\text { terhadap kecernaan NDF dan ADF } \\
\text { dibandingkan kontrol. Kombinasi } \\
\text { SC+AO meningkatkan nitrogen } \\
\text { intake. }\end{array}$ \\
\hline
\end{tabular}

Probiotik membentuk suatu substansi yang berfungsi sebagai kofaktor sehingga dapat meningkatkan penyerapan laktat oleh mikroorganisme rumen (Nisbet dan Martin, 1990a). Perlambatan pelepasan senyawa oligosakarida yang merupakan prekursor asam laktat (tahap 6).

\section{Kombinasi DFM S. cerevisiae dan A. oryzae pada Ternak Ruminansia}

Penelitian yang menggunakan

kombinasi beberapa jenis DFM telah dilakukan untuk mengoptimalkan produktivitas ternak. Amin (1977) menyatakan bahwa suplementasi kombinasi probiotik $S$. cerevisiae dan $A$. oryzae dapat meningkatkan fermentabilitas pakan dalam rumen in vitro. Hal ini disebabkan kerjasama yang sinergis kedua fungi tersebut. $S$. cerevisiae mampu menghasilkan enzim amilase yang berfungsi mencerna pati, sedangkan $A$. oryzae menghasilkan enzim selu-lase dan hemiselulase yang mampu mencerna serat kasar (selulosa dan hemiselulosa). Hal tersebut mendukung pernyataan Shin et al. (1989) yang menyatakan bahwa $S$. cerevisiae termasuk salah satu mikroba yang umum dipakai untuk ternak sebagai probiotik, bersama-sama dengan bakteri dan cendawan lainnya seperti Aspergillus niger, Aspergillus oryzae, Bacillus pumilus, Bacillus centuss, Lactobacillus acidophilus, Saccharomyces crimers, Streptococcus lactis dan Streptococcus termophilus.

Penambahan suplemen jamur (A. oryzae dan $S$. cerevisiae) dapat meningkatkan kecernaan bahan kering, produksi dan kualitas susu, serta bobot hidup ternak ruminansia (Alshaikh et al., 2002). Hal ini terjadi karena peningkatan jumlah bakteri selulolitik, peningkatan degradasi serat dalam rumen, dan perubahan kandungan asam lemak terbang (VFA) rumen. 


\section{KESIMPULAN}

Pemanfaatan DFM S. cerevisiae dan A. oryzae untuk ternak ruminansia dapat menguntungkan ternak melalui perbaikan ekosistem rumen. Suplementasi DFM pada ternak ruminansia dapat meningkatkan karakteristik cairan rumen, populasi mikroba rumen, perfomans dan produktifitas ternak ruminansia. Tetapi, tidak semua hasil penelitian menghasilkan respon positif walaupun sangat jarang yang memberikan dampak negatif. Oleh sebab itu, penambahan DFM dalam pakan ternak ruminansia juga harus memperhatikan jenis DFM yang akan digunakan baik secara individu ataupun kombinasi sehingga dapat terjadi kerjasama yang sinergis dari DFM untuk meningkatkan produktivitas ternak. Pemanfaatan DFM pada ternak ruminansia sangat disarankan di Indonesia, terutama untuk ternak ruminansia yang memperoleh pakan berkualitas rendah seperti limbah-limbah hasil pertanian atau perkebunan.

\section{DAFTAR PUSTAKA}

Amin. 1997. Pengaruh pengggunaan probiotik Saccharoyces cerevisiae dan Aspergillus oryzae dalam Ransum pada Populasi mikroba, Aktifitas fermentasi rumen, Kecernaan dan Pertumbuhan sapi perah dara. Thesis magister sains program Pascasarjana IPB, Bogor.

Arambel, M.J. dan B.A. Kent. 1990. Effect of yeast culture on nutrient digestibility and milk yield response in early-to mid lactation dairy cows. J. Dairy Sci 73: 1929-1932.

Alshaikh, M. A., A.Y. Alsiadi, S.M. Zahran, H.H. Mugawer and T.A. Aalshowime. 2002. Effect of feeding yeast culture from different sources on the performance of lactating holstein cows in saudi arabia. Asian-Australia. J. Animal. Sci. 15(3) : 352-355.

Beharka, A. A., T.G. Nagaraja and J.L. Morrill. 1991. Performance and ruminal function development of young calves fed diets with Aspergillus oryzae fermentation extract. J. Dairy Sci. 74:4326-4336.

Beharka, A.A., and T.G. Nagaraja. 1993. Effect of Aspergillus oryzae fermentation extract $\left(\right.$ Amaferm $\left.^{\circledR}\right)$ on in vitro fiber degradation. J. Dairy. Sci. 76:812-818.

Chen, C.R., B. Yu and P.W.S. Chiou. 2004. Roughage energy and degradability estimatiion with Aspergillus oryzae inclusion using dairy in vitro fermentation. Asian-Aust. J. Anim. Sci. 17:5362.

Chiquette, J. 1995. Saccharomyces cerevisiae and Aspergilus oryzae, used alone or in combination, as feed supplement for beef and dairy cattle. Agriculture canada research, Lenooxville, Quebec, Canada J1M $1 Z 3$ no. 483.

Cole, D..J.A . 1991 . The role of the nutrionist in design feed for future in feed industry. Proc. of Alltechs, Seventh Annual Symposium. Alltech Technical Publication, Nicholasville Kentucky : 12.

Dawson, K.A. 1990. Designing the yeast culture of tomorrow. Mode of action of yeast culture for ruminant and non ruminant. In: T.P. Lyons (ed), Biotecnology in the feed industry. Altech Technical Publications, Nicholasvillae, KY. Pp. 59-78.

Dawson, K.A. 1993. Current and future role of yeast culture in animal production : A Review of research over the last seven years. P. 269-291. In : T.P. Lyons (ed). Biotechnology in feed industry. Vol. IX. Alltech Technical Publications, Nicholasville, K.Y.

Denev, S.A., T.Z. Peeva, P. Radulova, N. Stancheva, Staykova, G. Beev, P. Todorova, S. Tchbanova. 2006. Yeast cultures in ruminant nutrition. Bulgarian Journal of Agricultural Science. 13. P. 357-374. 
Desnoyers, M., S. Giger-Reverdin, G. Bertin, C. Duvaux-Ponter and D. Sauvant. 2009. Meta-Analysis Of The Influence Of Saccharomyces Cerevisiae Supplementation On Ruminal Parameters And Milk Production Of Ruminant. J. Dairy. Sci., 92: 1620-1632.

Fuller, R. 1989. A Review : Probiotics in man and animals. J. Appl. Bacteriol. 66:365378 .

Fuller, R. 1992. History and Development of Probiotics. In Probiotics the Scientific basis. Edited by Fuller. Chapman and hall. London, New York, Tokyo, Melbourne, Madras. Pp. $1-7$.

Fuller, R., 2002, Probiotic- What they are and what they do. http://D:/Probiotic. What they and what do, html.

Gomez-Alarcon., C. Dudas, and J.T. Huber. 1989. Influence of culture of Aspergillus oryzae on rumen and total tract digestibility of dietary components. J. Dairy. Sci. 73: 703-710.

Grochowska, S.W. Nowak., R. Mikula, and M. Kasprowicz-Potocka. 2012. The effect Saccharomyces cerevisiae on ruminal fermentation in sheep fed hidh or low NDF rations. J. Anim. Feed. Sci. 21, 276-284.

Hobson, P.N. and J.P. Jouany. 1988. Models Mathematical and Biological, of the Rumen Function. The Rumen Microbial Ecosystem. P.N Hobson (ed.). Elseiver Science Publishers. London.

Hobson, P.N . and R.J. Wallace. 1982 . Microbial ecology and activities in the rumen . Part IL CRC Crit . Rev. Microbiol . $9: 253-320$.

Inal, F., E. Gurbuz, B. Coskun, M.S. Alatas, O.B. Citil, E.S. Polat, E. Seker, dan C. Ozcan. 2010. The effect of live yeast culture (Saccharomyces cerevisiae) on Rumen Fermentation and Nutrient Degradability in Yearling Lambs. Kakfas Univ. Vet. Fak. Derg. 16(5): 799-804.
Jouany, J.P. 2001. Twenty years of research and now more relevant than ever the coming of age of yeast cultures in ruminant diets. In : Responding to a Changing Agricultural Landscape. Alltech's European, Middle Eastern and African Lecture Tour, pp. 44-69.

Latief, M.R., S.M. Zahran, M.H. Ahmed, H.S. Zeweil and S.M.A. Sallam. 2014. Effect of feeding Saccharomyces cerevisiae and Aspergillus oryzae on nutrient uutilization and rumen fermentation characteristic of sheep. J. Agric. Res. Vol. 59, No. 2, pp. 121-127.

Li. J., D. F. Li, J. J. Xing, Z. B. Cheng and C. H. Lai., 2004. Effects of $\beta$-glucan extracted from Saccharomyces cerevisiae on growth performance, and immunological and somatotropic responses of pigs challenged with Escherichia coli lipopolysaccharide. Journal of Animal Science. 2006.No 84. Pp 2374-2381

Lubis, D., E. Wina, B. Haryanto, and T. Suhargiyantatm. 2002. Feeding Aspergillus oryzae Fermentation Culture (AOFC) to Growing Sheep: The Effect of AOFC on Rumen Fermentation. JLTV. Vol.7. No. 3.

McAllister. T.A., K.A. Beauchemin, A. Y. Alazzeh, J. Baah, R. M. Teather, and K. Stanford. 2011. Rivew : The use of direct fed microbials to mitigate pathogens and enhance production in cattle. J. Anim. Sci. 91: 1-19.

Mikulec, Z.,T. Masek., B. Habrun., and H. Valpotic. 2010. Ifluence of live yeast cells (Saccharomyces cerevisiae) supplementation to the diet of fattening lambs on growth perfomance and rumen bacterial number. Veterinarski Arhiv. 80 (6), 695-703.

Mustangwa, T., I.E. Edward, J.H. Topps and G. F. M. Peterson. 1992. The effect of dierty inclusion yeast culture (Yea-Saac) on pattern of rumen fermentation, food 
intake and growth of intensively fed bulls. Anim. Prod., 55: 35-40.

Mwenya, B., B. Santoso, C. Sar, Y. Gamo,T. Kobayashi, I. Arai and J. Takahashi. 2004. Effects of including 1,4-galactooligosaccarides, lactic acid bacteria rr yeast culture on methanogenesis as well as energy and nitrogen metabolism in sheep. Anim. Feed Sci. Technol., 115 : 313-326.

Newbold, C.J. 1990. Probiotics as feed additives in ruminant diets.51a Minnesota Nutrition Conference .pp . 102 -118.

Ngadiyono, N. dan E. Baliarti. 2001. Laju Pertumbuhan dan produksi karkas sapi Peternakan Ongle Jantan dengan penambahan probiotik starbio pada pakannya. Media Peternakan 24(2): 63-67.

Nisbet, D.J. and S.A. Martin. 1990a. Effect of dicarboxylic acids and Aspergillus oryzae fermentation extract on lactate uptake by ruminant bacterium Selemonas ruminantium. Appi Environ. Microbiol. 58 : 3515 -3518.

Oetzel, G.R., K.M. Emery, W.P. Kautz and J.E. Nocek. 2007. Direct-fed microbial supplementation and health and performance of pre- and postpartum dairy cattle: A field trial. J. Dairy Sci. 90:2058-2068.

Offer, N.W. 1990. Maximising fiber digestion in the rumen: The role of yeast culture . In : Biotechnology in the Feed Industry . LYONS, E .P . (Ed.). Alltech Technical Publications, Nicholasville, Kentucky . pp . 79-76.

Preston, T.R. and R.A. Leng. 1987. Matching ruminant production systems with available resources in the tropics and sub-tropics. Penambul Books: Armidale, Australia pp. 245.

Ritonga, H. 1992. Bakteri sebagai pemicu pertumbuhan. Poultry Indonesia No. 14/April , Hal : 11-13.
Roberfoid, M.B . 2000. Prebiotics and probiotics :are they functional foods 1-3 Am. J. Clin. New. 71 (Suppl) :1682816878.

Shin, T., S. Hyung, K. Kyun and A. Choong. 1989 . Effects of CYC on the performance of Dairy, Beef cattle and swine. Seoul, Korea.

Soeharsono. 1994. Probiotik (alternatif pengganti antibiotik dalam bidang peternakan) . Laboratorium Fisiologi dan Biokimia. Fakultas Peternakan. Universitas Padjajaran.

Sosa, A., J. Galindo, M.L. Tejido, A. Diaz, M.E. Martinez, C. Saro, M.D. Carro, and M.J. Ranilla. 2011. Effects of Aspergillus oryzae on in vitro ruminal fermentation. Options Mediterraneennes : Série A. Séminaires Mediterraneens; $n$. 99.

Wallace, R.J. and C.J. Newbold. 1992 . Probiotics for ruminants. In : Probiotics, the Scientific Basis. FULLER, R . (Ed .). Champan and Hall. London. pp . 317 -353 .

Wiedmeier, R.D., M.J. Arambel and J.L. Waltern. 1987. Effect of yeast culture and Aspergillus oryzae fermentation extracts on ruminal characteristics and nutrient digestibility. J. Dairy Sci. 70:2063.

William, P.E.V. 1989 . The mode of action of yeast culture in ruminant diets : A review of the effect on rumen fermentation patterns . In : Biotechnology in the Feed Industry . LYONS, T .P. (Ed .). Altech Technical Publication, Nicholasville. Kentucky. pp . 65 - 84.

William, P.E.V., C.A.G . Tait, G.M . Innes and C.J . Newbold. 1991. Effect on the inclusion of yeast culture in the diet of dairy cow on milk yield and forage degradation and fermentation patterns in the rumen of sheep and steers . J . Anim Sci . 69 : 3016 -3026. 
Wina, E. 2000. Pemanfaatan ragi (yeast) sebagai pakan imbuhan untuk meningkatkan produktivitas temak ruminansia. Wartazoa 9(2) : 50-56.

Yano, T.M. dan Ito, K.T., 1998. Purification and Properties of Glutaminase From Aspergillus Oryzae. J. Ferment.Technol. 6(2): 137-142.

Yoon, I.K. and M.D. Stern. 1995. Influence of direct-fed microbials on ruminant microbialfermentation and performance of ruminants: A review. Asian-Aust. J. Anim. Sci. 8:533-555.
Yoon, I.K. and M.D. Stern. 1996. Effect of Saccharomyces cerevisiae and Aspergillus oryzae cultures on ruminal fermentation in dairy cows.

Zain,M., N. Jamarun dan Elihasridas. 2002. Suplementasi rumput dengan jerami olahan dalam ransum ternak sapi. J.Andalas. No.31/Mei/Tahun XI.

Zain,M, N. Jamarun,A.Arnim, W.S.N. Ningrat and R.Herawati 2011. Effect of Yeast (Saccharomyces cerevisiae) on fermentability, microbial population and digestibility low quality roughage (in vitro). Archiva Zootecnica 14(4): 51-58. 